\title{
Participants' interaction in infrastructure projects of the municipal-private partnership
}

\author{
Marina Tsurkan ${ }^{1, *}$, Irina Dokukina ${ }^{2}$, Alexey Artemiev ${ }^{3}$ \\ ${ }^{1}$ Tver Branch of the Russian Academy of National Economy and Public Administration under the \\ President of the Russian Federation, 7, Vagzhanova str., 170100, Tver, Russia \\ ${ }^{2}$ Central Russian Institute of Management Branch of RANEPA, 5A, Boulevard Pobedy, 302028, Orel, \\ Russia \\ ${ }^{3}$ Tver State Technical University, 22 A, Nikitin emb., 170026, Tver, Russia
}

\begin{abstract}
The article systematizes the idea of the participants' interaction in thr infrastructure projects of municipal-private partnerships through an ecosystem approach. Required and non-mandatory project participants, as well as an algorithm for their interaction in the framework of the municipalprivate partnerships' ecosystem, which is classified as "Ecosystems of infrastructure partnership" in the article, are identified. A methodological apparatus has been developed and organizational models for the construction or reconstruction of the municipal-private partnerships infrastructure projects are formed. The models are proposed to be divided into basic and varied, the latter are essentially summary and may include from one to three optional elements.
\end{abstract}

\section{Introduction}

Currently, the public-private partnership mechanism implementation in the Russian Federation is still at the implementation stage in most regions. At the same time, the smallest number of projects for the construction and reconstruction of social, transport, energy or communal infrastructure in the interaction framework between the authorities and business structures was carried out at the municipal level. According to the information posted on the Rosinfra infrastructure project support platform, only about 40 projects under consideration are currently being implemented.

In part, this can be explained by the poor development of a methodology for the interaction of participants in infrastructure projects, especially the functions in the process of construction and (or) reconstruction of the object under agreement.

At the same time, the work of many scientists in the field of management, construction economics and the regional economy, who at the same time did not analyze the possibility of creating an infrastructure facility in the context of the ecosystem approach, is devoted to the business structures and local governments' interaction study as a tool for mutually beneficial partnerships.

\footnotetext{
*Corresponding author: 080783@list.ru
} 
The possibilities and limitations of the municipal-private partnerships, which are characteristic for each of the interaction parties, as well as various approaches to defining the corresponding concept, are considered in the works by A. Burkov [1], T.N. Gladun [2], M.V. Elesina [3], B.M. Zhalsanova and E.A. Shevchenko [4], E.D. Razgulina [5], S.A. Kozhevnikov and T.V. Uskova [6], V.S. Kharitonov [7].

In the works of A. Burkov, it was noted that in the process of implementing the infrastructure projects of the municipal-private partnership "business receives new investment objects that have stable demand from the local population. Local governments release a part of the budget that previously was to finance these facilities" [1].

T.N. Gladun [2], B.M. Zhalsanova, E.A. Shevchenko [4] consider the partnership of business structures and local authorities as the main, general tool for the effective socioeconomic territorial development.

B.M. Zhalsanova and E.A. Shevchenko defines the partnership in question as "the mutually beneficial cooperation of local authorities with Russian or foreign legal entities, individual entrepreneurs, associations of legal entities, which is carried out by the conclusion and execution of agreements, including concession" [4].

It should be noted that in the framework of this study, the author does not consider the concession agreements as the basis for the municipal-private partnerships' implementation, believing that the conditions created for the concession projects' implementation created under 115-FL can only be described as one of the types of intersectoral interaction.

M.V. Elesina concretizes some aspects of municipal-private partnership, notes that this interaction "should be understood as a form of contractual agreement between the authorities and business entities, providing the active use of technical, financial and managerial resources of the private sector to achieve the tasks set by the municipalities" [3].

V.S. Kharitonov defines the investigated partnership as an instrument of "financial support of the municipality's investment policy" [7].

Such definitions have the right to exist, but require clarification in accordance with Federal Law No. 224-FL, according to which, municipal-private partnership is "legally registered for a certain period of time and based on pooling resources, sharing risks, public partner's cooperation with on the one hand, and a private partner, on the other hand, which is carried out on the basis of the municipal-private partnership agreement, in order to attract private investment into the economy, to ensure local governments the availability of goods, work, services and improve their quality".

It should be noted that a private partner cannot be a foreign legal entity, as well as an individual entrepreneur, and the basis for this partnership is the infrastructure being created.

V.I. Kataeva and R.A. Gubin, studying the features of introducing the mechanism of municipal-private partnership in the housing sector, note that within its framework "accelerated implementation of significant investment projects is possible (modernization of engineering networks and existing technologies of housing and communal services enterprises, development of energy saving programs, installation of common house metering devices, etc.)" [8].

The object composition of municipal-private partnerships was studied in the article by L.G. Yelkibaeva, who proposes a conceptual change in respect of the project facilities by signing the agreements only with respect to movable property [9], which, in our opinion, may have legal grounds, but it is not advisable taking into account the socio-economic effects that may be obtained from the infrastructural projects' implementation in the municipal territory.

The French institutionalists L. Boltanski and L. Theveno, within the framework of the economic coordination school, noted that "the active role of the organization-enterprise, political party, state, is to work out the compromises in the agents' interactions" [10]. 
As noted by G.A. Sologubova: "any enterprise is part of an ecosystem, regardless of whether it agrees with it or not, only the enterprise's ability to extract the maximum benefit from its participation in this ecosystem is of importance" [11].

Considering the municipal-private partnership from this point of view, with a mandatory refraction on the ecosystem approach, it can be stated that the interaction being investigated is based on the organizational and economic compromise, the result of which is the development of the infrastructure in the project implementation area.

The purpose of the article is to systematize the ideas about the participants' interaction in the municipal-private partnership projects by identifying the mandatory and optional agents of their ecosystem, determining the interaction algorithm and possible models for creating and (or) reconstructing the infrastructure object created under the agreements.

\section{Ecosystem of the municipal-private partnership's infrastructure projects: concept and participants}

At the present stage, in the municipal-private partnerships infrastructure projects' ecosystem, it is possible to distinguish the mandatory and additional participants.

Mandatory participants include:

- A representative of the business community acting as a private partner;

- A public partner, who is the head of the municipality or another person authorized to provide the municipality, an element of the local government system;

- An authorized body of the municipal level, determined in accordance with the municipality charter, which is not a public partner and is essentially a communicator between the partners in the pre-project phase and the accompanying structure in the infrastructure project's implementation;

- An authorized body at the regional level, most often its functions are performed by the regional project office in the constituent entities of the Russian Federation or some element of the structure of the department or ministry in the region responsible for economic development;

- The head of the municipality, which may not act as a public partner, but is an obligatory participant in the infrastructure projects, as it makes a decision on the project's implementation, which may be negative even if the project's effectiveness identified in the evaluation and the confirmed comparative advantage, which calculated on the basis of methods approved at the federal level and reflects the feasibility from the infrastructure facility construction or reconstruction budgetary effects' position within the framework of a municipal-private partnership, rather than a municipal contract.

Additional participants in municipal-private partnership infrastructure projects include:

- a financing person who provides a business structure acting as a private partner, borrowed funds, if necessary;

- legal entities or bodies that may be the participants in the infrastructure projects at the invitation of a public partner, performing the functions within the framework of monitoring the execution of the municipal-private partnership agreement on.

It should be noted that the relationship between a public partner and a private one is defined in the agreement signed only between these participants in the ecosystem, regardless of whether a financing entity was involved by the business structure and for a period of at least 3 years.

Enlarged, the interaction algorithm of participants in the municipal-private partnerships' ecosystem is presented in Figure 1. 


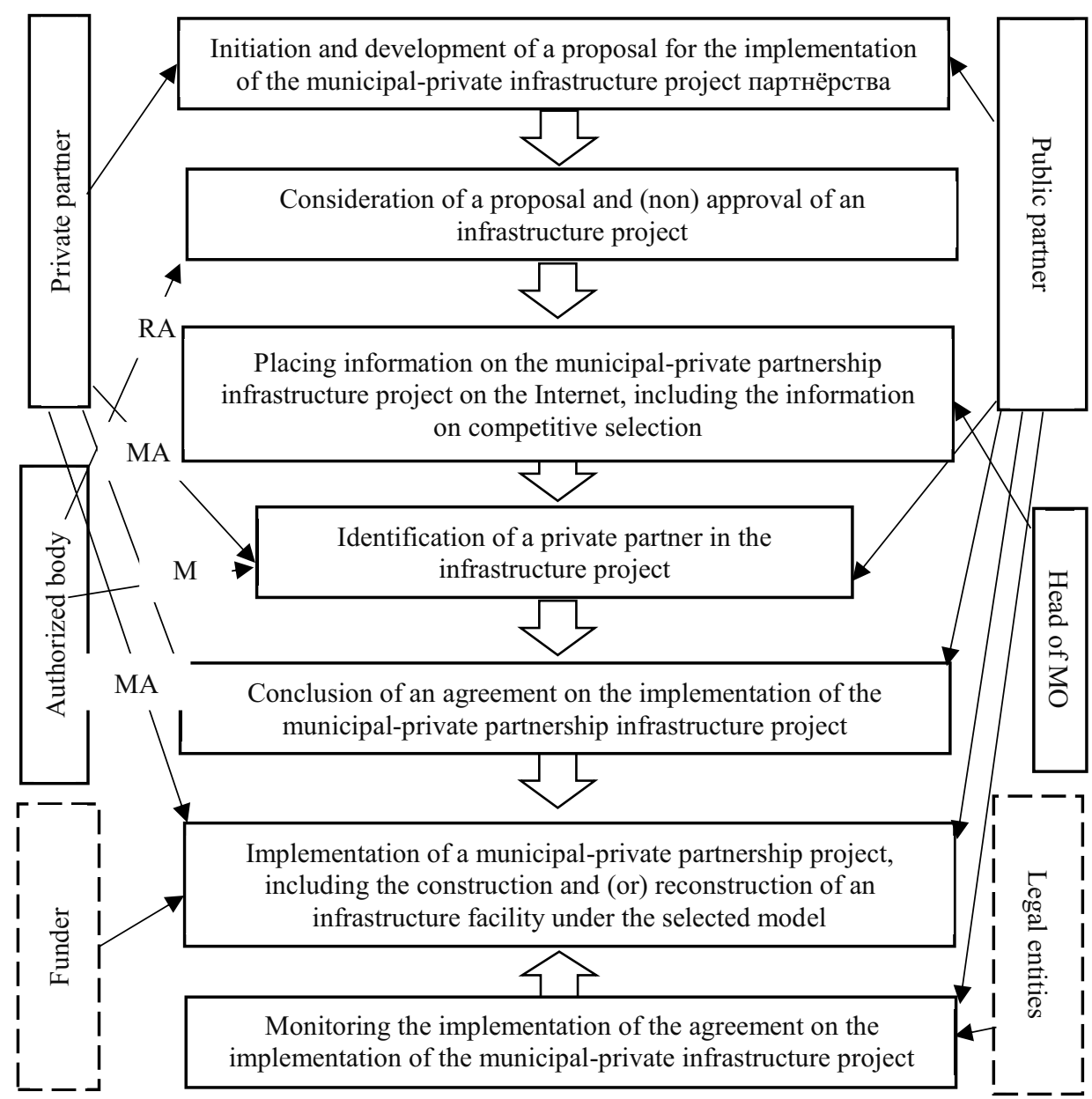

Fig. 1. The algorithm of the participants' interaction in the municipal-private partnership infrastructure projects.

If a sponsor is involved, the relationship between a public partner, a private partner and this potential ecosystem's participant is established as a part of a direct agreement.

For example, an additional participant in municipal-private partnership projects may be the State Order Committee, which has been created in many constituent entities of the Russian Federation and can provide methodological support in monitoring the municipalprivate partnership agreement implementation with the financial participation of a public partner.

As noted by G.A. Sologubova, in modern literature there are five types of ecosystems (five ecosystem building strategies) in which the companies "live": an ecosystem of platforms, an ecosystem of innovations, an ecosystem of interests, an ecosystem of commerce, an ecosystem of things [11].

This approach is designed for organizational and economic relations arising in the implementation of $\mathrm{B} 2 \mathrm{~B}$ processes and cannot be adapted as a classification part of the ecosystem under consideration, for the identification of which the author suggests introducing the concept of "infrastructure partnership ecosystem".

The infrastructure partnership ecosystem is a set of interconnected legal and official persons united around the construction and (or) reconstruction of an infrastructure facility, 
which is created on the basis of an economic and organizational compromise, in the conditions of equal opportunities for financial and property participation in the process of public and private partners, as well as equal distribution of responsibility for the project implementation risks.

\section{Models for the infrastructure facilities' creation in the municipal-private partnership infrastructure projects' framework}

Prior to the entry into force of Federal Law No. 224-FL, the foreign developments (WTO, DBFO, SBI, BOT, BOOT, VOMT, DBOOT), reflecting the sequence of the partnership stages and the amount of authority transferred to the private partner, were recognized as possible models of public-private partnerships by the domestic scientists [12], most of which, within the framework of the current legal framework, have lost their relevance.

The analysis of relevant regulatory sources revealed 186 possible models of interaction between the business structures and local authorities in the framework of municipal-private partnerships.

In the framework of the author's approach, one should distinguish between the basic partnership models and the additional ones. The last of which are total, that is, are formed due to the complementary elements' addition.

To specify the concepts introduced, the following definitions can be proposed:

"The basic model of municipal-private partnership is a mandatory set of the project elements that reflects the participation sequence of a business partner in the project, as well as the amount of powers transferred to it under an agreement with a local government.

The total model of municipal-private partnership is a sequence built on the basis of one of the basic models, reflecting not only the scope of possible mandatory powers under a specific agreement with the local government, but also the additional powers of both parties" [13].

The basic models of municipal-private partnerships can be identified as follows:

1. CCOP (Creation - Co-financing - Operation - Property);

2. CFOP (Creation - Financing - Operation - Property);

3. CCTE (Creation - Co-financing - Technical Servicing - Property);

4. CFMP (Creation - Financing - Maintenance - Property);

5. CCOMP (Creation - Co-financing - Operation and Maintenance - Property);

6. CFOMP (Creation - Financing - Operation and Maintenance - Property).

The basic models are self-sufficient, they reflect the variability of the possible mandatory competencies of business structures in partnership projects.

Additional elements include the following elements: design, co-financing of operation, financing of operation, co-financing of maintenance, financing of maintenance, co-financing of operation and maintenance, financing of operation and maintenance, financing of operation by a municipality, financing of maintenance by a municipality, financing of operation and technical services by the municipality, property of the municipality.

That is, the summation of 11 additional elements forms: 11 total models of the first stage, 10 total models of the second stage and 9 total models of the third stage.

We give examples of summary models using an example CCOP.

The total model of the first stage $(\mathrm{CCOP}+)$ - Creation - Co-financing - Operation Ownership with Property of the municipality.

The total model of the second stage $(\mathrm{CCOP}++)$ - Design - Creation - Co-financing Operation - Financing of operation and maintenance by a municipality-Property. 
The total model of the third stage $(\mathrm{CCOP}+++)$ - Design - Creation - Co-financingOperation - Co-financing of technical services-encumbered property-Property of the municipality.

It should be noted that the element "Property of the municipality" will be mandatory, under one condition, if the total amount of the project co-financing and the cost of municipal property transferred to the private partner for the project's implementation exceeds the amount of co-financing of the project by the private partner.

Currently, most projects are being implemented or planned to be implemented within the framework of CFOP, CFMP and CFOMP models.

It should be noted that for the period of the first quarter of 2020, almost 4 times fewer projects were initiated than for the first quarter of 2019. Of course, this aspect can be explained by a decrease in business activity due to the self-isolation regime.

However, in our opinion, in the near future we can expect an increase in the number of projects implemented on the basis of the CCOMP, CCT, CCES models and their additional variations. In conditions of uncertainty, the models involving co-financing from a public partner can be considered the basis for an equal distribution of risks among the main participants in the ecosystem.

\section{Summary}

The study allowed us to draw the following conclusions, the main of which are as follows:

- the municipal-private partnership infrastructure projects' implementation implies the possibility of participation in them, both mandatory and non-mandatory agents, and the decision on the construction and (or) reconstruction of a specific project is made by the head of the municipality on which territory the work is planned;

- municipal-private partnership projects are implemented within the framework of an ecosystem that cannot be classified on the basis of the existing approaches that reflect the possibility of only B2B interaction;

- to expand the existing classification approaches, the concept of "Infrastructure Partnership Ecosystem" can be introduced, which should be understood as a set of interrelated legal and official persons united around the construction and (or) reconstruction of an infrastructure object, which is created on the basis of an economic and organizational compromise, in the equal opportunities conditions for financial and property participation in the process of public and private partners, as well as equal distribution of responsibility for the project implementation risks.

- models for creating an infrastructure object can be divided into main and additional, within the framework of the author's concept, the complementary models can be divided into total models of the first, second and third degrees;

- the methodology for the additional summary models' formation is to increase the number of the complementary elements of the agreement to one of the basic models, while the number of such elements varies from one to three;

- basic models for the municipal-private partnership projects' implementation reflect the key components for the construction economy that determine the basis of economic relations between the partners, which allows calculating the social and economic effects that can be obtained from creating an infrastructure facility for each of the parties.

The results of the study are of practical importance for public authorities, specialists in project management, construction, investors, and methodologists in the field of the ecosystem approach. 


\section{References}

1. A. Burkov, Self management 5, 6-7 (2012)

2. T.N. Gladun, Actual problems of our time: science and society 1(2), 30-33 (2014)

3. M.V. Elesina, Bulletin of modern science 1(1), 61-64 (2015)

4. O.S. Shevchenko, B.M. Zhalsanova, Bulletin of the Transbaikal State University 7, 122$126(2014)$

5. E.D. Razgulina, Territory development problems 5(73), 78-90 (2014)

6. T.V. Uskova, S.A. Kozhevnikov, Economic and social changes: facts, trends, forecast 6 (36), 34-46 (2014)

7. V.S. Kharitonov, Bulletin of modern science 1(1), 61-64 (2015)

8. V.I. Kataeva, R.A. Gubin, Materials of the Ivanovo readings 1-2(11), 144-152 (2017)

9. L.G. Elkibaeva, Local law 1, 53-60 (2018)

10. L. Boltanski, L. Theveno, Criticism and justification of justice: Essays on the sociology of cities (Scientific trans. NOT. Kolosov, Moscow, 2013)

11. G.S. Sologubova, Components of digital transformation: monograph (Yurait Publishing House, 2020)

12. A.A. Kozlov, Public-private partnership: essence, classification Entrepreneurship 2(38) (2012) http://www.uecs.ru/uecs-38-382012/item/1053-2012-02-20-06-19-20

13. M.V. Tsurkan, O.A. Nikulenko, Scientific electronic archive (2015) http://econf.rae.ru/article/9702 